\title{
O wyższości teraźniejszości nad przeszłością — albo na odwrót. Retoryczne sposoby hiperbolizacji medialnej dwu kategorii*
}

Celem tekstu jest językowa analiza opozycji przeszłość-teraźniejszość obecnej w tekstach publicystycznych polskich tygodników społeczno-politycznych: „Newsweek Polska” (dalej: N), „Polityka” (dalej: P), „Wprost” (dalej: W). Wybór uwarunkowany został kilkoma istotnymi założeniami: tygodniki należą do grupy pism ogólnopolskich, opiniotwórczych, są często cytowanymi, wiarygodnymi źródłami prasowymi. Ponadto, czasopisma te według Polskich Badań Czytelnictwa $^{1}$ spośród wszystkich tygodników społeczno-politycznych są najchętniej czytane. Należy również wskazać, że wybrane tytuły prasowe reprezentują liberalną, progresywistyczną orientację. Wreszcie, istotny jest także sprofilowany odbiorca pism, który charakteryzowany jest jako czytelnik ponadprzeciętny, czytelnik-inteligent. Te zbieżności, zwłaszcza w prezentacji podobnego/identycznego światopoglądu, pozwalają na wysunięcie hipotezy o realizacji badanej opozycji w sposób podobny czy też jednorodny.

Interesować mnie będą sposoby opisu relacji temporalnej w kontekście kreowania nadzwyczajności, którą rozumiem jako kategorię retoryczną — zespół mechanizmów retorycznych, m.in. eksponujących ekscytujące tematy oraz ewokujących ciekawość. Ekscytujący temat jest równoznaczny z treścią sensacyjną, natomiast ciekawość powiązana jest z emocjami zaskoczenia i zadziwienia.

* Artykuł jest częścią projektu finansowanego ze środków Narodowego Centrum Nauki przyznanych przyznanych na podstawie decyzji numer DEC-2013/09/N/HS2/02283.

1 Dane za okres od sierpnia 2011 roku do stycznia 2012 roku: „Press” 2012, nr 4. Badania czytelnictwa prasy tygodniowej w latach 2001-2011 (przedział czasowy, z którego pochodzi materiał źródłowy pracy) pokazują stałość wyboru wskazanych trzech tytułów w segmencie tygodników społeczno-politycznych. 
Nadzwyczajność jako kategoria na wskroś dialektyczna - ujawniająca się przez binarność: zwyczajność i niezwyczajność - najpełniej wyraża się przez zestawienia. Komplementarne względem siebie pary opozycyjne podzielone są z uwzględnieniem hierarchicznej kolejności: pierwsza antypoda jest nadrzędna i dodatnio wzmacniana, przy czym należy zauważyć, że nadrzędność jest wynikiem określania i uzupełniania jej przez drugą antypodę. Taka dyspozycja uwydatnia de facto ich pozorną opozycyjność, wkomponowane są w nią bowiem elementy wzajemnie się definiujące, a zatem wchodzące z sobą w dialog. Argumenty tworzone na podstawie konstrukcji porównawczych, czy to na zasadzie podobieństwa, czy kontrastu, są dodatkowo ilustratorami uruchamiającymi wyobraźnię, dzięki czemu odbiorca komunikatu łatwiej percypuje przekazywaną treść. Zestawienie, które powstaje na podstawie nierównorzędności cech, jest zaklasyfikowane jako argument $\mathbf{z}$ porównania (a comparatione), wypełnienie porównania polega zaś na zbliżeniu rzeczy większych z mniejszymi i na odwrót (Korolko 1990, s. 66). Większość badaczy dostrzega w tym zabiegu osobny sposób argumentowania: argument ze wzmocnienia (a fortiori), wszak dzięki przewyższającym bądź znoszącym się treściom uwypuklony zostaje walor ekspresywny i wzmocniona zostaje perswazyjność komunikatu.

Argument $\mathrm{z}$ porównania ujawnia się także $\mathrm{w}$ temporalnych zestawieniach: teraźniejszości z przeszlością oraz teraźniejszości z przyszlością. Należy zauważyć, że użycie perspektyw czasowych wiąże się z modelowymi założeniami prezentacji tematu przez prasę opiniotwórczą: rozległość perspektywy czasowej, tj. teraźniejszość z uwzględnieniem historii i umiejętnością projektowania przyszłości, przy wykorzystaniu zależności przyczynowo-skutkowych. Dwa zestawy — korespondujące skądinąd $\mathrm{z}$ argumentum a tempore — można przedstawić za pomocą schematów:

\section{PRZESZłOŚĆ}

TERAŹNIEJSZOŚĆ

Schemat 1. Argument z porównania: zestawienie przeszłość-teraźniejszość Źródło: opracowanie własne.

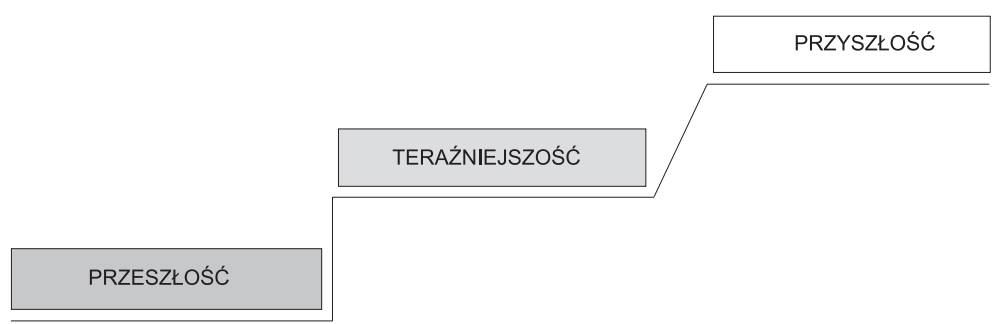

Schemat 2. Argument z porównania: zestawienie przeszłość-teraźniejszość-przyszłość Źródło: opracowanie własne. 
które wykluczają się wzajemnie, w pierwszym przypadku teraźniejszość jest bowiem wartością podrzędną, w drugim zaś nadrzędną. Schemat 1. należy interpretować jako zniesienie założonej, projektowanej przez powszechną świadomość niezwykłości czasów obecnych (nadrzędność przeszłości). Hic et nunc jest w swoisty sposób pozbawione walorów nadzwyczajności przez egzemplifikacyjne przywołania przeszłości, która utkana z barwnych faktów/ciekawostek historycznych dezaktualizuje naj- pierwszej dekady XXI wieku, sprawiając, że zjawiska współczesności powszednieją. Exempla funkcjonują na zasadzie równoczesnego przewyższenia/zaniżenia - zarówno implicytnego, jak i eksplicytnego - tego, co nadawca perswazyjnie z sobą zestawia. Wypowiedź o charakterze argumentacyjnym można przedstawić w postaci formuły: X, a zatem Y (por. Tokarz 2006, s. 128), uwzględniając także pozostałe wymienne warianty połączone innymi spójnikami.

[1] Jedną z najbardziej popularnych rozrywek wśród XVI-wiecznych paryżan było palenie kota. Zawieszano go nad sceną, a następnie opuszczano powoli w płomienie ogniska. [...] Okrucieństwo jako popularna rozrywka, składanie ofiar z ludzi w imię przesądów i zabobonów, niewolnictwo jako metoda obniżania kosztów pracy, ludobójstwo w imię czystości etnicznej, tortury i okaleczanie jako rutynowe formy karania, pogromy jako sposób rozładowania frustracji - wszystkie te zjawiska stanowily nieodlączny element życia przez większą część historii ludzkości ... Dziwnie to pewnie zabrzmi, ale wiek XX, z jego stu milionami ofiar, również może napawać optymizmem. Gdyby skala przemocy była podobna jak w poprzednich stuleciach, liczba ofiar XX w. wzrosłaby wielokrotnie (Przyszłość. Czy ludzkość ma powody do optymizmu, P 2009, nr 4).

[2] Już w czasach Hipokratesa, a więc $w \mathbf{V}$ w. p.n.e., prymitywna $z$ naszego punktu widzenia medycyna wiedziała, jak rozprawić się z wrogiem w postaci guza - szybko wyciąć albo wypalić. Problem w tym, że zanim nowotwór wypełznie na światło dzienne z ukrytej pod skórą tkanki albo ujawni się w postaci odczuwalnej dolegliwości, upływa sporo lat, więc starożytni lekarze posługujący się jedynie własnym wzrokiem i dotykiem niewiele mogli chorym pomóc (Polowanie na raka, P 2004, nr 28).

Historia odgrywa tu rolę szczególną — właściwa jej narracyjność, gawędziarskość, a także atrakcyjność oraz staranna selekcja fragmentów przeszłości przez nadawcę $\mathrm{w}$ istocie ewokują wrażenie, że wszystko już było, a zdarzenia opisywanej codzienności przestają być najstraszniejsze, najniezwyklejsze, najtragiczniejsze czy najbardziej szokujące $[1,2]$.

Schemat 2. przedstawia relację nadrzędności teraźniejszości nad podrzędną przeszłością oraz jednoczesne spotęgowanie teraźniejszości i przedłużenie jej w przyszłość. W tej retorycznej konfiguracji hic et nunc jest bardziej wyjątkowe: już bardzo dobre/innowacyjne, z potencjałem na jeszcze lepsze/bardziej innowa- 
cyjne. W tym miejscu można przywołać również przybliżającą odbiorcę do wydarzenia koncepcję partykularyzacji: „wydobywanie szczególności, wyjątkowości danego wydarzenia" (Skibiński, Wasilewski 2008, s. 235). Kreowana przestrzeń niezwykłej dynamiczności, przełomowości będzie miała swoje realizacje również $\mathrm{w}$ toposie przełomu. Opisywany czas jest przekraczaniem tego, co było dotychczas, co więcej - zerwaniem z przeszłością, choć z tej przeszłości wyrosłym. Punkt styczny znajduje się w przyszłości, która jest wzmocnionym continuum teraźniejszości. Strukturę argumentacyjną można przedstawić w postaci: X już był, ale Y jest wzmocniony, dlatego Y jest lepszy.

[3] Stworzenie zwierzęcia myślącego jak czlowiek to kwestia niedalekiej przyszłości. Pierwszy krok został zrobiony — wyhodowano mysz z ludzkimi komórkami mózgu. Chimera, mityczne zwierzę z głową lwa, tułowiem kozła i ogonem węża, istniała w wyobraźni starożytnych, budząc grozę. Dzisiaj wcale nie mniejszym strachem napawają chimery powstające w uniwersyteckich i prywatnych laboratoriach na calym świecie: pól zwierzęta, pół ludzie. Stworzono myszy z układem immunologicznym człowieka [...]. Jednak prawdziwy przełom nastąpil przed kilkoma tygodniami, kiedy to naukowcy z Salk Institute for Biological Studies w Kalifornii pod kierunkiem wybitnego neurobiologa Freda Gage'a wyhodowali mysz z żywymi komórkami człowieka, funkcjonującymi w ich mózgach (Mysz z ludzkim mózgiem, N 2006, nr 9).

[4] Homorodziny w Polsce istnieją. Najwięcej takich, gdzie dwie lesbijki wychowują biologiczne dzieci jednej z nich. Takie sytuacje zdarzały się od lat, ale zawsze trzymane były w tajemnicy. Dziś pojawiają się pionierki, które chcą o tym rozmawiać: $\mathrm{z}$ własnymi dziećmi, rodziną, bliskim otoczeniem, a nawet publicznie, choć zazwyczaj anonimowo (Mamy lesmamy, P 2008, nr 26).

$\mathrm{W}$ tej postaci argumentu z porównania historia pełni funkcję li tylko drugiego — choć nadal barwnego - planu, który ma służyć zwiększeniu pola intensywności czasów teraźniejszych, a także, choć nie zawsze, przyszłych. Należy zauważyć, że niejednokrotnie teraźniejszość wyrasta z przeszłości - przeszłość stanowi więc swoistą matrycę — jednak w tym ujęciu to jedynie teraźniejszość zostaje wzmocniona. A odkrycie przez czytelnika, że obecne jest wynikiem przeszłego, czyli uświadomienie sobie intertekstualności czasów, czy nawet rozpoznanie znanego w nowym, jest swojego rodzaju przyjemnością:

Nadmiar wywołuje obojętność lub ustawiczne poszukiwanie nieokreślonej nowości, czegoś, co mogłoby - zarówno w estetycznym, jak i etycznym wymiarze — „Zaskoczyć”, „wstrząsnąć”, wprawić w zdumienie lub przerażenie. Mówiąc inaczej: możemy czerpać przyjemność zarówno z możliwo- 
ści odczytania znanego w nieznanym, jak i niemożliwości odczytania znanego w nieznanym, $\mathrm{z}$,Zamieszkiwania” w świecie [M. Heidegger - P.P.], jak i z poczucia „wyobcowania”, „bezdomności”, „nomadyczności” (Bauer 2009, s. 97).

Kategorię nadzwyczajności konstytuuje zatem zasada wyjątkowości, jak również ambiwalentne mechanizmy rozpoznania i nierozpoznania, implikujące ciekawość, a także zaskoczenie.

Temporalne porównania bezpośrednio korespondują z zestawieniem nowoczesność-tradycja, która jest jedną $\mathrm{z}$ realizacji argumentu $\mathrm{z}$ przeciwieństwa (a contrario). Proces argumentacyjny polega na zestawieniu z sobą przynajmniej dwóch równorzędnych - w odróżnieniu od argumentu z porównania - rzeczy, których cechą dyferencyjną jest zwrot wektora wartości. Zbliżenie przeciwstawnie waloryzowanych treści jest równoznaczne z użyciem antytetonu, figury podkreślającej dialektyczność retoryki (analityczność i perswazyjność), a także zamykającej perswazję we wzmocnieniu wrażenia, w końcu ,zestawiającej pojęcia lub obrazy przeciwstawne dla lepszego ich uwydatnienia" (Korolko 1990, s. 111). Ponadto kontrast dobrze służy uporządkowaniu wypowiedzi, rozdzieleniu, wyznaczeniu granic (Skibiński, Wasilewski 2008, s. 231). Arystoteles pisał o figurze tak: „Już same przeciwieństwa bardzo ułatwiają zrozumienie myśli, a jeszcze bardziej, gdy występują obok siebie; również dlatego, że sprawiają wrażenie logicznej argumentacji (sylogizmu): sylogizm obalający polega bowiem na zestawianiu przeciwieństw" (Arystoteles 1978, s. 50). Z kolei M. Rusinek pisze o antytezie jako „figurze rozumu, pomagającej w pojmowaniu świata” (Rusinek 2012, s. 15), gdyż udowodnione jedno ramię antytetonu będzie zaświadczać o nieprawdziwości, a w przypadku nadzwyczajności: słabości/niewyrazistości. Warto przytoczyć także myśl K. Burke'a:

Wiemy w każdym razie, że nawet czysto formalne wzory mogą budzić w nas postawę wspomagającego oczekiwania. Wyobraźmy sobie tekst zbudowany z szeregu opozycji (,,my robimy to, lecz oni ze swej strony robią tamto; my stoimy tutaj, a oni idą tam; my patrzymy w górę, lecz oni spoglądają w dół itd.). W momencie, w którym rozpoznajemy tendencję zawartą w formie, narzuca nam się ona jako zaproszenie do współpracy, bez względu na treść, jaką przenosi. Kieruje nami rytm następstwa antytez — nawet wtedy, gdy nie zgadzamy się z prezentowanymi w tej formie twierdzeniami. Mogą to być nawet twierdzenia oponenta, budzące nasze oburzenie - a mimo to w trakcie samej wypowiedzi będziemy „pomagać” w ich „spełnianiu się”, poddając się logice formalnego rozwoju wypowiedzi i symetrii jej formy (Burke 2008, s. 49).

Dualistyczne konstruowanie przestrzeni ujawniające się w sekwencji skądinąd atrakcyjnych percepcyjnie — antytez jest zatem perswazją szczególną, jak wskazuje powyżej K. Burke, jej celem jest bowiem nie tyle przystępne przed- 
stawienie treści koniecznych do zaakceptowania przez odbiorcę, ile nastawienie na uczestnictwo w procesie rozumowania, tudzież apelowanie do odbiorcy o podjęcie tego uczestnictwa, a taki punkt widzenia pozwala myśleć o perswazyjności argumentu w kontekście atrakcji.

Najczęściej występują dwa człony antytezy, zdarza się jednak, że jeden z dwóch elementów jest automatycznie presuponowany i wyłącznie implicytnie obecny (jak w przypadku nadrzędności/podrzędności). Tradycję należy rozumieć jako zbiór obyczajów, norm, konwencji, przyzwyczajeń, nowoczesność z kolei jako kontrpropozycję dla tego zbioru. Przy okazji uwalniane są konotacje otwartości i postępowości, które przynależą do nowoczesności, na mocy kontrastu dalej tradycja jest negatywnie nacechowana. Antyteton oparty na kontrastowym zestawianiu starego z nowym widać w poniższych przykładach:

[5] Dotychczas dominował pogląd, że między wiekiem przedszkolnym a dojrzewaniem istnieje aseksualny okres utajenia. Nowe badania seksualności dzieci i młodzieży rzucają jednak nowe światło na to, co się dzieje przed okresem dojrzewania (Seks od kotyski, W 2010, nr 9).

[6] Polscy seniorzy nie zamierzają przechodzić na seksualną emeryturę. Chętnie nawiązują romanse, nie wstydzą się leczyć impotencji, a życie erotyczne urozmaicają gadżetami z sex-shopów. I tylko przed swoimi dorosłymi dziećmi ukrywają, że w podeszlym wieku nadal uprawiają seks. [...] Milość seniorów tradycyjnie już rozkwita na Uniwersytetach Trzeciego Wieku, w domach starców, a przede wszystkim w sanatoriach (Starość radość (erotyczna), W 2011, nr 28).

Siła zestawienia polega nie tylko na samym kontraście mocno ugruntowanym w tradycji retorycznej i kulturowej, lecz także eksploracji obszarów objętych społecznym tabu. Wkroczenie na te obszary równoznaczne z jednoczesnym wykroczeniem poza obowiązujące standardy może skutecznie skupić uwagę czytelnika i może być postrzegane jako efektowny proces zjednywania sobie odbiorcy. Zabieg ten połączony z podkreśleniem relatywnie długiej obecności we współczesności wprowadzanej nowej — pozornie, jak się okazuje — treści, co najczęściej wyrażone jest za pomocą okoliczników już (starożytni)..., dawno temu..., można uznać za eskalację ekspresji. Podobnie jak w przypadku porównania teraźniejszości i przeszłości, można zauważyć wskazanie na aspekt przedawnienia, jednak mechanizm dezaktualizacji jest inny niż w opozycji teraźniejszość-przeszłość, wypływa bowiem z efemerycznej natury prezentowanej nowoczesności. W takim ujęciu czytelnik przemierza dwa dynamiczne etapy: 1) zainteresowanie wskazanym novum, 2) zainteresowanie wskazaniem na powszechność wprowadzonego dopiero co novum.

Nadzwyczajność poprzez argument z przeciwieństwa ewokuje najczęściej zaskoczenie. Emocje, które okalają spolaryzowaną linię nowoczesność-tradycja, to $\mathrm{w}$ równej mierze ciekawość, co strach, determinowane przez uzasadnienie 
z nowości (argumentum ad novitam) (por. Lewiński 2008, s. 55). Według teorii afektów retorycznych wszystko, co nowe - zwłaszcza obudowane najnowszymi badaniami naukowymi, o czym będzie mowa w kolejnych partiach tekstu — może rozbudzać ciekawość przez nieznane, może budzić lęk przez nieoswojone. Ostatnie odczytanie koresponduje z argumentem do bojaźni, trwogi (argumentum ad metum), który kieruje ku „instynktownemu lękowi przed nieznanym: przyszłością, zmianami, niepewnością jutra" (Szymanek 2001, s. 58). Nowość implikującą ciekawość Z. Bauer umieszcza w sformułowaniu:

Urok oryginału tkwi w jego swoistej dysfunkcjonalności wobec naszych oczekiwań, bowiem obcując z rzeczą nową, nie potrafimy jeszcze określić naszych oczekiwań: rozpoznajemy siebie w tej rzeczy. Sytuacji takiej nigdy nie zapewni kopia: kopia jest zawsze „funkcjonalna”, zawsze „dookreślona” i zamknięta na wszelki przypadek, na wszelki poznawczy dysonans i niezdolna do wywołania w nas zdumienia (Bauer 2009, s. 96).

Nowe, obok wymienionych, może konotować także lepsze i słuszne, co najlepiej widać na przykładzie komunikatów reklamowych i właśnie medialnych. Przeciwstawny wobec argumentum ad antiquitatem jest przykład argumentacji retorycznej, a ściślej erystycznej.

Topos przelomu jest skorelowany z uzasadnieniem z nowości (zwłaszcza odkrycia naukowe), a także z porównaniami temporalnymi w ten sposób, że wymienione argumenty właściwie ogniskują się w toposie z przełomu, a sam topos stanowi soczewkę skupiającą wartości z reguły konotacyjnie dodatnie: wiedzę, postęp, nowoczesność. Jako figura „monumentalna” — przez wzgląd zarówno na hiperonimiczność toposu wobec zbieżnych argumentów właściwych, jak i jego zwartość — reprezentuje wypowiedź argumentacyjną wprowadzającą bezalternatywność i hiperboliczność. Topos jest stopniowalny, co oznacza, że natężenie przełomowości rzeczy można przedstawić w skali rozpoczynającej się od zmiany, nowego spojrzenia [7], a kończącej się na odkryciu obszaru zupełnie nieobjętego eksploracją albo czynności doniosłej czy wręcz epokowej [8]. Warto jednak zauważyć, że locus jest daleki od toposu rewolucji, gdyż figura nie tylko nie odsyła do tematów wielkich momentów historycznych, lecz także nie zakłada całkowitego zburzenia porządku, który silnie negatywnie waloryzuje. Przełom jest łagodniejszy w swej wymowie, implikuje ciągłość między dotychczasowością a teraźniejszością, w końcu jest zmianą, a nie demonstracyjną zamianą czy wymianą. Topos przełomu zazwyczaj pośrednio/bezpośrednio odnosi się do wartości, którą zastępuje, i jest to powiązanie kontrastywne, jednak nie skrajnie pejoratywne, co pozwala sądzić, że figura zbudowana jest na antytetonie. Z kolei, jeśli topos odsyła do przestrzeni zupełnie nowych, niezbadanych, to prezentuje proces budowania tych miejsc od nowa, a eskalacja, która towarzyszy temu budowaniu, koncentruje się wokół samego uczestnictwa w przełomowości. Należy jednakże podkreślić, że fascynacji odkryciem towarzyszy zawsze uzasadnienie, 
zatem jest to kreowanie atrakcji połączone $\mathrm{z}$ wartością poznawczą (por. Pleszczyński 2010, s. 82-83).

[7] Uczeni poszukują skutecznych sposobów pozbywania się z pamięci traumatycznych zdarzeń. I są już o krok od stworzenia leku kasującego przykre wspomnienia. Tygodnik naukowy „Science” opublikowal bardzo ciekawy raport $z$ badań przeprowadzonych przez psychologów z University of Colorado. Poprosili oni uczestników eksperymentu o zapamiętanie 40 par zdjęć. Każda składa się z neutralnej emocjonalnie fotografii ludzkiej twarzy oraz obrazka wywołującego silne negatywne odczucia, na którym widniały np. zdjęcia wypadków drogowych, rannych żołnierzy lub egzekucji na krześle elektrycznym. [...] Czy w ten sposób ci, którzy byli świadkami tragicznych wydarzeń, mogą próbować zatrzeć te wspomnienia? Zdaniem Depue, mogłoby się to udać po dłuższym treningu (Pigułka niepamięci, P 2007, nr 30).

[8] W ostatnich latach na temat funkcjonowania mózgu dowiedzieliśmy się znacznie więcej niż przez kilka poprzednich stuleci. Ale wciąż towarzyszy nam dramatyczne pytanie: czy ludzki umysł potrafi zrozumieć jak działa mózg? I czym jest świadomość? Amerykański myśliwiec F-22 wlatuje w sam środek burzy. Silne podmuchy wiatru rzucają maszyną, ale pilot bardzo sprawnie utrzymuje ją na zaplanowanym kursie. Myśliwiec bez problemów pokonuje gęste, ciemne chmury. Nie jest to jednak prawdziwy samolot, tylko jego wirtualna kopia, istniejąca w grze komputerowej, jaką można kupić w sklepach na całym świecie. Nie byłoby w tym nic zaskakującego, gdyby za sterami F-22, czyli przed klawiaturą komputera, siedział wielbiciel symulatorów lotu. Ale nikogo tam nie ma - krzesło stoi puste. $Z$ obudowy komputera wychodzi natomiast kabel podłączony do szklanej szalki laboratoryjnej. Na niej natomiast znajduje się 25 tys. żywych komórek nerwowych pobranych z mózgu szczura i sztucznie podtrzymywanych przy życiu. To właśnie one sterują supernowoczesnym myśliwcem F-22! Science fiction? Absolutnie nie! (Śmierć duszy, P 2010, nr 20).

Nadzwyczajność oparta na toposie przełomu jest nader ekspresywna, a uwalnianie emocji jest procesem zgoła naturalnym. Towarzyszą zatem przełomowi zarówno ciekawość, jak i zadziwienie, które uzupełniane są przez poczucie ujawniania tajemnicy. Konstrukcje topiczne nie zawsze przyjmują postać zdania twierdzącego, a są formułami pytań intensyfikujących zainteresowanie. Zdarza się także, że odkrywany przedmiot nie jest pozytywnie wartościowany, opatrzony przez nadawcę negatywnym znakiem wartości, wówczas ewokowane jest poczucie obawy czy strachu. Nadawca i odbiorca wiedzą, czego można po danym rejestrze oczekiwać i jakie bodźce zostaną potencjalnie pobudzone. Przestrzeń toposu nie może być stygmatyzacją (jak w przypadku rewolucji), natomiast do- 
puszczalna jest kategoryzacja na linii rzeczywistość przełomu (+)-rzeczywistość sprzed przełomu (-). Cel topicznej projekcji można zamknąć w ramie modalnej: „odbiorco, poczuj/zrozum”, gdyż percepcja przełomowości tożsamej z niezwykłością jest $\mathrm{w}$ założeniu najistotniejsza. Zainteresowanie dokonaniami naukowo-technicznymi można powiązać z dążeniem do obrazowania nieustannego progresu możliwości cywilizacji oraz odkrywczego potencjału natury ludzkiej.

Należałoby choćby zaznaczyć, że przeciwstawny wobec toposu przełomu jest topos ad fontes, paralelnie powiązany z opozycją temporalną przeszłość-teraźniejszość. W odróżnieniu od przełomu, proces ukazywania czy też docierania do źródła jest eksponowaniem wyższości przeszłości nad teraźniejszością. Sam proces dochodzenia do źródła, docierania do prapoczątku jest opatrzony dodatkowym ładunkiem ekscytacji, ma naturę wprost sensacyjną. Mechanizm kreowania nadzwyczajności jest wspierany jednocześnie przez efektowne zaprzeczenie oryginalności wytworów nowoczesności, które jest tym silniejsze, jeśli towarzyszy mu zmiana wektora wartości. Kategorią kluczową jest tutaj powrót. Nie jest to wycieczka w czasie łaskawa dla współczesności, gdyż odkrywa - słowo nieprzypadkowe - prawdę odzierającą współczesność z jakichkolwiek oznak sensu stricto nadzwyczajności. Jedyna nadzwyczajność, jaką można dostrzec, to kreacja medialna zaskoczenia zlokalizowanego w tym odkryciu.

Analiza opozycji przeszłość-teraźniejszość prowadzi do wniosku, że czołowe tygodniki społeczno-polityczne w Polsce, o zbieżnym, liberalnym profilu, przedstawiają kategorię temporalną w sposób podobny, mocno podkreślając znaczenie teraźniejszości. Nie znaczy to jednak, że przeszłość jest zupełnie nieistotna, pojawia się bowiem $\mathrm{w}$ kontekstach typowo retorycznych. Z perspektywy językoznawczej, retorycznej konfrontację dwóch wartości antytetonu: przeszłość-teraźniejszość można przedstawić za pomocą argumentu z porównania w postaci wprost wyrażonej relacji temporalnej oraz argumentu z przeciwieństwa realizowanego przez zestawienie nowoczesność-tradycja. Kategorie czasu można także zaobserwować na przykładzie obecnych w tekstach toposów: przełomu oraz ad fontes. Wszystkie wskazane mechanizmy retoryczne służą celom perswazyjnym, a ściślej realizacji strategii hiperbolizacji przekazu. Operowaniu kategoriami czasu towarzyszy wyolbrzymienie w tym sensie, że w zależności od kontekstu jeden z członów - albo przeszłość, albo teraźniejszość (tudzież przyszłość) - staje się kategorią nadrzędną, perswazyjnie przewyższającą drugi. Można więc mówić, w zależności od założonego celu, o powiększeniu/pomniejszeniu znaczenia przeszłości lub teraźniejszości. To hiperboliczne zestawianie jest zaś jednym z retorycznych narzędzi kreowania nadzwyczajności w tekście medialnym, polegającym na wzbudzaniu ciekawości skorelowanej z sensacyjnością wiedzy, palimpsestowością, potrzebą odkrywania oraz weryfikacji i/lub falsyfikacji. 


\section{Bibliografia}

Arystoteles (1978), Topiki. O dowodach sofistycznych, przeł., wstępem i komentarzem opatrz.

K. Leśniak, Warszawa.

Bauer Z. (2009), Dziennikarstwo wobec nowych mediów. Historia, teoria, praktyka, Kraków.

Burke K. (2008), Tradycyjne zasady retoryki, przeł. K. Biskupski, [w:] Retoryka, red. M. Skwara, Gdańsk.

Korolko M. (1990), Sztuka retoryki. Przewodnik encyklopedyczny, Warszawa.

Lewiński P.H. (2008), Retoryka reklamy, Wrocław.

Pleszczyński J. (2010), Przestrzeń aksjologiczna mediów popularnych i jakościowych, Tabloidyzacja języka i kultury, red. I. Kamińska-Szmaj, T. Piekot, M. Poprawa („Oblicza Komunikacji” nr 3), Wrocław, s. 75-88.

Rusinek M. (2012), Retoryka obrazu. Przyczynek do percepcji teorii figur, Gdańsk.

Skibiński A., Wasilewski J. (2008), Prowadzeni stowami. Retoryka motywacji w komunikacji publicznej, Warszawa.

Szymanek K. (2001), Sztuka argumentacji. Stownik terminologiczny, Warszawa.

Tokarz M. (2006), Argumentacja, perswazja, manipulacja. Wyktady z teorii komunikacji, Gdańsk.

\section{Superiority of the present on the past - or the other way round. Rhetorical methods of media hyperbolizing of the two categories}

\section{Summary}

The aim of the paper is a linguistic analysis of the future - present opposition employed by the opinion-forming weeklies in Poland: Newsweek Polska, Wprost, Polityka. The article presents ways of describing the temporal relation in the context of creating extraordinariness. The opposition is represented by the group of rhetorical tools (argumentum a comparatione, argumentum a contrario, locus nomen, locus ad fontes) leading to hyperbolizing the message.

Keywords: extraordinariness, rhetorical tools, hyperbole, opinion-forming weeklies 